\title{
EVALUATION OF BAMBARA GROUNDNUT VARIETIES FOR OFF-SEASON PRODUCTION IN ZIMBABWE
}

\author{
I. MAKANDA, P. TONGOONA, R. MADAMBA ${ }^{1}$, D. ICISHAHAYO ${ }^{2}$ and J. DERERA \\ African Centre for Crop Improvement, University of KwaZulu-Natal, P/Bag X01 Scottsville, South Africa \\ ${ }^{1}$ Crop Breeding Institute, P. O. Box CY550 Causeway, Harare, Zimbabwe \\ ${ }^{2}$ Department of Crop Science, University of Zimbabwe P.O. Box MP167 Mt Pleasant, Harare, Zimbabwe
}

(Received 23 January, 2009; accepted 20 July, 2009)

\begin{abstract}
Early planting of bambara groundnuts (Vigna subterranea L. Verdc) in the southern Africa enables farmers to fetch premium prices before the markets are flooded with produce from the main summer growing period. However, adaptation of the crop outside the main growing season has not been studied in Zimbabwe. Therefore, this study evaluated 20 varieties at four planting dates covering contrasting temperatures and daylength, at Harare Research Station, during 2000/2001. Planting date was the main plot factor replicated three times and cultivar the subplot. Standard agronomic practices were followed and adequate moisture supplied through supplementary irrigation. Both the planting dates and variety main effects were significant $(\mathrm{P}<0.05)$ for yield and most of the secondary traits. Planting date $x$ genotype interaction ( $G \mathrm{x} E$ ) effects were not significant $(\mathrm{P}<0.05)$ for yield, suggesting that cultivars were relatively yield stable. However, $\mathrm{G} x$ E effects were significant $(\mathrm{P}<0.05)$ for days to $50 \%$ emergence and pod count plant ${ }^{-1}$. Differences among varieties were attributable to genotypic effects and different photothermal conditions. August and September planting dates resulted in high dry pod yield. Varieties BS599, BS537, V2-17, BS520, and Variety-10, had high relative yield, and were the most promising for off-season planting.
\end{abstract}

Key Words: Genotype x environment, planting date, Vigna subterranea

\section{RÉSUMÉ}

La sémis précoce des arachides bambara (Vigna subterranea l. Verdc) permet aux agriculteurs de se procurer de bénéfices importants avant que les marchés ne soient inondés par la production réalisée en période de croissance normale. Toutefois, l'adaptation de la culture en dehors de la saison de croissance principale n'avaiit pas été étudiée au Zimbabwe. Par conséquent, une étude avait été menée afin d'évaluer 20 variétés à quatre différentes dates de sémis couvrant des températures variées et la longueur de la journée, à la station de recherche de Harare, au cours de 2000/2001. La date de plantation avait été le facteur principal répliquées trois fois et le cultivar le facteur subordonné. Les pratiques agronomiques standard avaient été observées et une humidité adéquate fournie par le biais d'une irrigation supplémentaire. Les dates de plantation aussi bien que et les variétes comme effets principaux avaient été significatives $(\mathrm{P}<0.05)$ pour le rendement et la plupart des traits secondaires. Les effets de la date de sémis $\mathrm{x}$ interaction génotypique ( $\mathrm{G} \mathrm{x} \mathrm{E})$ n'étaient pas significatifs $(\mathrm{P}<0,05)$ pour le rendement, ce qui donne à penser que les cultivars étaient de rendement relativement stable. Toutefois, les effets $\mathrm{G} x \mathrm{E}$ étaient significatifs $(\mathrm{P}<0,05)$ pour les jours à $50 \%$ d'émergence et le comptage de gousse par plante. Les différences entre les variétés étaient attribuables aux effets génotypiques et aux différentes conditions photothermales. Les dates de plantation d'Août et Septembre, ont entraîné un rendement élevé en gousse sec. Les variétés BS599, BS537, V2-17, BS520, et variety-10, avaient un rendement relativement élevé et avaint été les plus prometteuses pour la plantation hors saison.

Mots Clés: Génotype x environnement, la date de plantation, Vigna subterranean 


\section{INTRODUCTION}

Bambara groundnut (Vigna subterranea L. Verdc) is grown mainly as a food crop in summer in Zimbabwe and the rest of southern Africa. The crop has been under-utilised and underresearched although it is highly nutritious. It has been traded informally which largely explains the low hectarage (Chibudu, 1995). However, recent events have seen an increase in its importance and a shift in status from subsistence to a cash crop. Apart from being consumed at home, it is now canned at a commercial level. In a survey in Chivi (southern Zimbabwe), Chibudu (1995) reported that traders from around the country and across borders were increasingly buying the crop at Ngundu market at an average price of US\$ $0.50 \mathrm{ka}^{-1}$, while Swanevelder (1998) reported up to US\$ 0.30 in South Africa. The crop is, therefore, becoming an important economic product.

Recent market research showed that $80 \%$ of consumers prefer fresh to dry pods (Rosalia Madamba, 2009, Crop Breeding Institute, Zimbabwe, pers. comm.). It is, therefore, important to promote early planting to ensure availability of the fresh pods for an extended period of time on the market. This will satisfy the demand by consumers, fetch premium prices for the farmer, and promote consumption of this nutritious crop. It also has the advantage of disease escape, especially foliar diseases due to reduced humidity during off-season planting. These benefits have prompted farmers to plant their crop as early as possible. However, available varieties have not been developed for early planting and farmers take risks with available main season varieties. Therefore, there is need to identify and develop suitable cultivars for this purpose cannot be over emphasised.

Developing cultivars for off-season planting entails selection under off-season conditions, because bambara groundnut's phenology is dependent on temperature and photoperiod (Nikishitani et al., 1988; Linnemann, 1991; Linnemann, 1993; Linnemann and Azam-Ali, 1993; Mkandawire and Sibuga, 2002). Bambara groundnut genotypes have been shown to exhibit variable responses to different planting dates (Linnemann, 1994: Karikari et al., 1995).
Nikishitani et al. (1988) reported shorter photoperiods to reduce number of pods plant ${ }^{-1}$, while Linnemann (1993) reported failure to pod under very long days of 14 to $16 \mathrm{~h}$. Linnemann (1994) further reported podding to be quantitatively induced by photoperiods below $12 \mathrm{~h}$ after exposing the plant to a genotypespecific number of days under a $12 \mathrm{~h}$ photoperiod. Further more, photoperiod was reported to influence partitioning of photoassimilates, with daylength of 14 and $16 \mathrm{~h}$ favouring vegetative growth and that of $13 \mathrm{~h}$ and below favouring pod and seed growth (Linnemann, 1993). Early pod induction results in decreased yield whereas, late pod induction results in elevated yields due to more vegetative growth and a more synchronized development (Linnemann, 1994).

Germination of bambara groundnuts increase from $16.8^{\circ}$ until $32.5^{\circ} \mathrm{C}$, where it reaches a peak and declines until $39.5^{\circ} \mathrm{C}$ (Karikari et al., 1995). It usually takes seven to 15 days under favourable temperature $\left(28.5\right.$ to $32.5^{\circ} \mathrm{C}$ ) for bambara groundnut to germinate; but under lower temperatures, it takes up to 31 days with some seeds remaining dormant indefinitely (Linnemann and Azam-Ali, 1993; Swanevelder, 1998). Soil temperature is, therefore, critical at the time of planting to ensure optimum germination and plant establishment. This has a bearing on early planting in southern Africa where winter temperatures are low. As a result, early planting is more likely to be affected by low soil temperatures through delays in germination and induction of dormancy in some seeds. This can result in poor plant stands.

Agronomic evaluations have shown that bambara groundnut has high yield potentials. Madamba (1995) reported yield of $0.3 \mathrm{t} \mathrm{ha-1}$ under marginal conditions and up to $4.2 \mathrm{t} \mathrm{ha}^{-1}$ with improved cultivars under optimum conditions. This was comparable to ranges of $3.0 \mathrm{t} \mathrm{ha}^{-1}$ reported for landrace in Tanzania (Collinson et al., 2000) and South Africa (Swanevelder, 1998). Landrace varieties still dominate the area under bambara groundnut production in southern Africa, which is a clear indication that limited breeding efforts have been put on the crop.

The objective of this study was to evaluate bambara groundnut genotypes, both landrace 
and improved varieties, for off-season planting in Zimbabwe.

\section{MATERIALSAND METHODS}

Experimental site. Twenty bambara groundnut varieties, 16 improved and four landraces (Table 1), were evaluated at four planting dates (Table 2) at the Harare Research Station (17 3/4 S; 31 E; 1480 m.a.s.l) in Zimbabwe. The fields are on red clay soil, classified as 5E.2 on the Zimbabwean classification system, Rhodic Paleustalf (USDA classification), or Chromic Luvisol on the FAO system (Nehanda, 2000). The mean annual rainfall for the site is $815 \mathrm{~mm}$ with reliable distribution over 19.2 rainy pentads. Monthly temperature varies, but is lowest during winter season (May to July), and highest in summer (November to April). During this study, both minimum and maximum planting temperatures were lowest in July and highest in October (Table 2). Day lengths vary from the winter levels of below $11 \mathrm{~h}$ to summer levels of up to $14 \mathrm{~h}$ (GAISMA, 2007). The planting dates selected cover the whole range of possible early planting times from winter (July) to the onset of summer (October).

Experimental design and management. The study was conducted using a split-plot arrangement in a randomised complete block design, with three replications. Planting date was the main plot factor with four levels, representing off-season and beginning of on-season planting times, while the cultivar was the subplot factor with 20 levels. The 20 varieties were randomly allocated to the 20 plots within the planting dates. The gross plot size was $3.2 \mathrm{~m}$ by $1.8 \mathrm{~m}$, and one seed was planted per station at $0.20 \mathrm{~m}$ within-row and $0.45 \mathrm{~m}$ inter-row spacing. A $150 \mathrm{~kg} \mathrm{ha}^{-1}$ of compound basal fertiliser [N (5\%): $\mathrm{PO}_{5}(17 \%)$ : $\mathrm{K}_{2} \mathrm{O}$ (10\%); B (0.25\%)] was applied by hand before planting. The field was kept weed-free by hand weeding and moisture stress was avoided through irrigation.

Parameters measured and data analysis. Parameters measured included number of days to first and $50 \%$ seedling emergence; number of days to first and $50 \%$ flowering; number of days to $95 \%$ physiological maturity; number of pods plant $^{-1}$, and dry pod yield plot ${ }^{-1}$. Dry pod yield plant ${ }^{-1}$ was estimated by dividing the mean cultivar yield plot $^{-1}$ by the number of plants plot $^{-1}$ at harvest. Relative variety pod yield was calculated as the mean cultivar pod yield plot $^{-1}$ divided by the overall trial mean pod yield plot $^{-1}$. All quantitative data were analysed with GenStat (Payne et al., 2007), and Principal Component biplots were constructed to present cultivar $x$ planting date interaction relationships.

\section{RESULTS AND DISCUSSION}

Planting date effects. There were significant differences $(\mathrm{P}<0.05)$ between planting dates for days to first and 50\% emergence, days to $50 \%$ flowering, days to $95 \%$ physiological maturity, number of plants plot $^{-1}$, and dry pod yield plot $^{-1}$ (Table 3). Days to first and 50\% emergence (Fig. 1a), days to first and $50 \%$ flowering (Fig. 1b), and days to $95 \%$ physiological maturity (Fig. 1d) decreased from the July planting (JP) to the October planting (OP) with the steepest decline observed between the JP and August plantings (AP). A similar trend was observed for dry pod yield (Fig. 1c) and plant establishment, with maximum yield observed for the September planting (SP) (Fig. 1e). The JP resulted in the longest time to emergence for all the varieties (Fig. 1a), which could be attributed to lower soil temperatures associated with the JP than the AP to OP. This observation was consistent with previous findings by Linnemann and Azam-Ali (1993) and Karikari et al. (1995), who reported that low temperatures delayed germination and seedling emergence. The effects of low ambient temperature were also observed on flowering dates because the JP took the longest time to onset and 50\% flowering (Fig. 1b), 95\% physiological maturity (Fig. 1d). It also exhibited lower plant counts plot $^{-1}$ at harvest (Fig. 1c) than the other three planting dates. The days to maturity were more than the in-season times of 102 - 115 days reported in Zimbabwe by Chibudu (1995), but the OP (Fig. 1d) was comparable to the 111 - 134 days and 110 - 150 days ranges reported for Tanzania and South Africa by Collinson et al. (2000) and Swanevelder (1998), respectively. However, there were similar $(\mathrm{P}>0.05)$ days to $50 \%$ flowering (Fig. 1b) for the other 


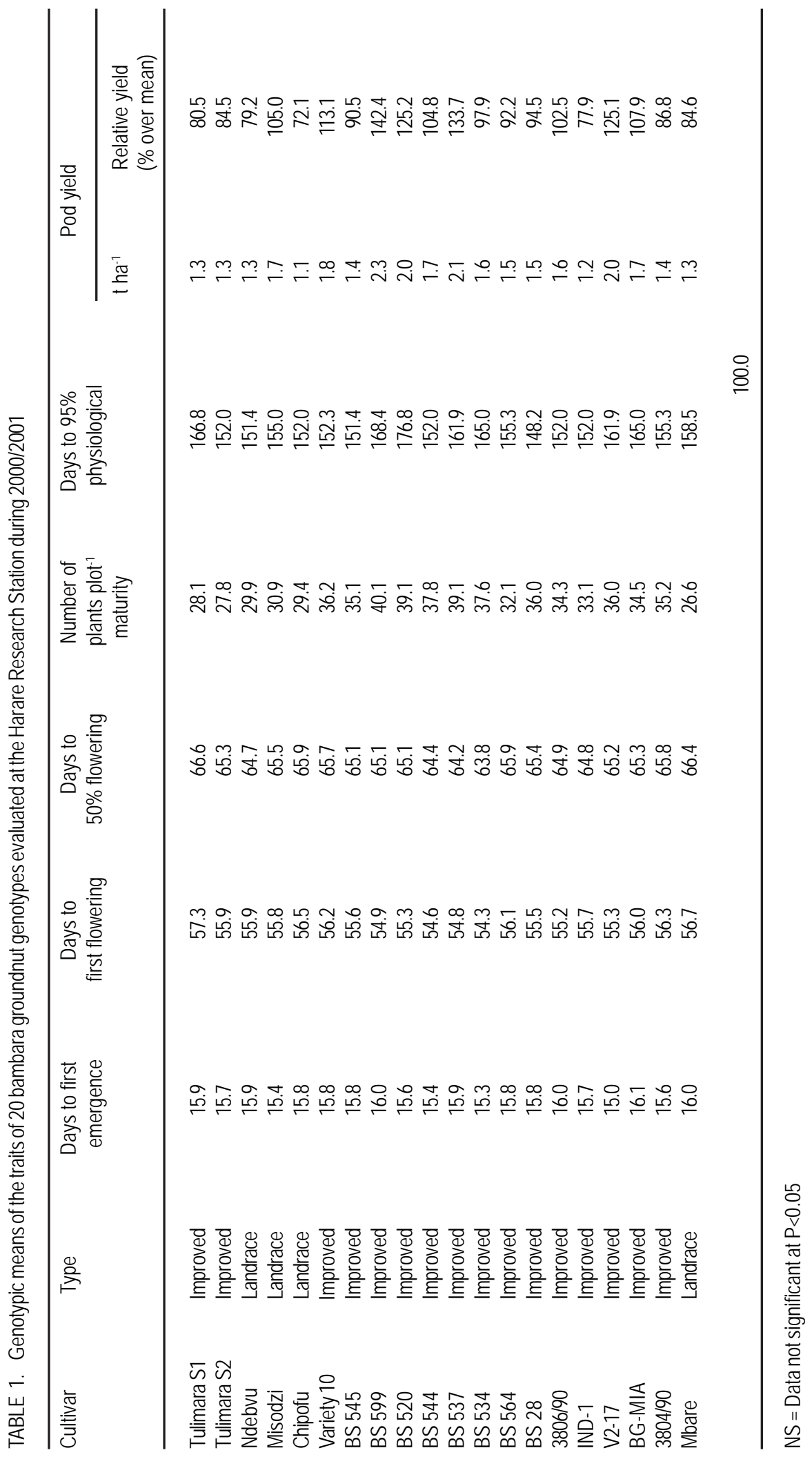


TABLE 2. Planting dates and their respective monthly temperature means at which the cultivars were evaluated

\begin{tabular}{llcc}
\hline Planting date & Season & \multicolumn{2}{c}{ Temperature $\left({ }^{\circ} \mathrm{C}\right)$} \\
\cline { 3 - 4 } & & Minimum & Maximum \\
\hline 17 July & Off-season & 5.8 & 20.5 \\
28August & Off-season & 7.3 & 21.8 \\
15 September & Off-season & 11.2 & 26.8 \\
22 October & In-season & 13.0 & 28.1 \\
\hline
\end{tabular}
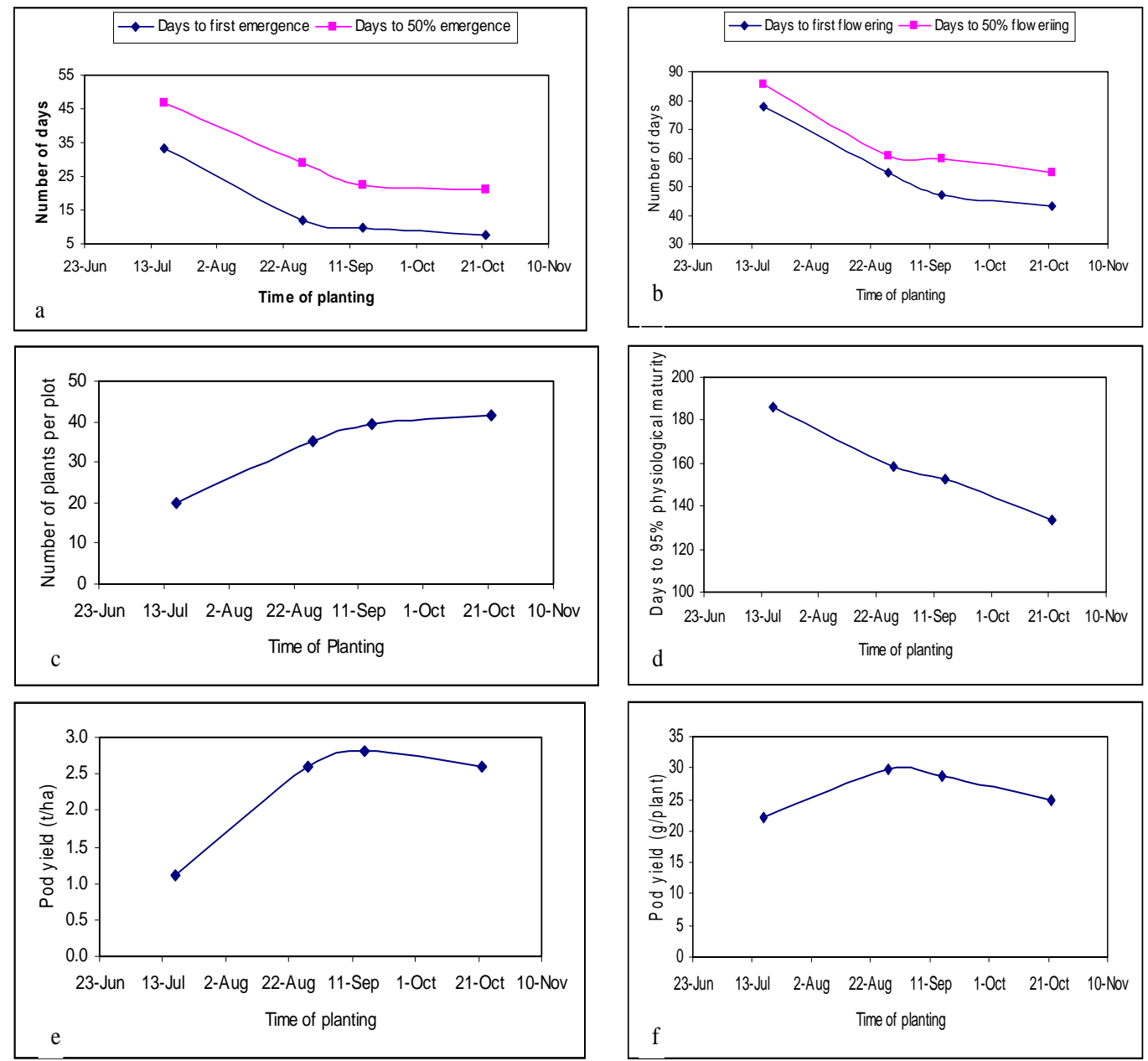

Figure 1. Mean trait values and trends across the four planting dates at the Harare Research Station during 2000/2001. SEDs for the traits: days to first emergence $=1.0$, days to $50 \%$ emergence $=3.75$, days to flowering $=2.55$, days to $50 \%$ flowering $=3.45$, number of plants per plot $=3.9$, days to $95 \%$ maturity $=2.45$, pod yield per plot $=15.95$. 
planting dates, which can be attributed to favourable temperatures and daylengths during the crop phenology during this period.

Although pod yield increased significantly $(\mathrm{P}<0.05)$ between the JP and AP, and optimum pod yield was observed with the SP (Fig. 1e), it was statistically similar $(\mathrm{P}>0.05)$ for the AP, SP and OP (Fig. 1e). Yield differences between the JP and rest of the planting dates can be attributed to JP's poor plant establishment due to low soil temperatures at germination. Low early growth temperature could also be responsible for the same trend observed for pod yield on a per plant basis where JP had lower than the other three planting dates (Fig. 1f). The OP, which had the highest plant stands (Fig. 1c), yielded the same as AP and SP (Fig. 1e) which are all associated with warmer temperatures than the JP. This implied negative competition between plants as plant stands increased above the optimum levels. Therefore, cold soil tolerant genotypes that can germinate rapidly and quickly establish a crop in July should be identified to enhance yield in winter production if planting is to be done as early as July in Zimbabwe.

Variety effects. Varieties BS599, BS537, BS520, BS544, BS534, Variety-10, V2-17, BS28, 3804/90, BS545, BG-M1A, and 3806/90 had large plant populations established even when planted under colder conditions in July (Table 1). This suggests that they might have been tolerant to low ambient soil temperatures. The observed yields are comparable to the $3.0 \mathrm{t} \mathrm{ha}^{-1}$ reported for landraces in Tanzania (Collinson et al., 2000) and for experimental entries in South Africa (Swanevelder, 1998). Chipofu, Tulimara-S2, 3806/ 90, IND-1, BS544, BS545, Ndebvu, and BS28 took the shortest time (Table 1) to reach 95\% physiological maturity, indicating that they are early maturing; while the rest could be classified as intermediate to late maturing. The times to maturity of the varieties on the SP and OP are comparable to the times (132-145 days) reported for Zimbabwe by Madamba (1995). Varieties BS599, BS537, V2-17, BS520, and Variety-10 showed high dry pod yield both per hectare with relative yield ranging from 142 to $113 \%$ (Table 1). Apparently, these cultivars combined high plant establishment with high single plant yield and 
long maturity period which contributed to high overall dry pod yield (Table 1). The high pod yield of BS520 and BS599, for example, can be in part, attributed to long pod filling period.

The mean values of landrace versus improved varieties were computed and compared between the two groups. The landraces, which combined early maturing period (154.2 days) with poor plant stand $(65.8 \%)$ displayed a lower yield potential $\left(1.9 \mathrm{t} \mathrm{ha}^{-1}\right)$ than their improved counterparts, which took 158.5 days and had a $78.0 \%$ establishment and a yield potential of $2.3 \mathrm{tha}^{-1}$. Although there was lack of balance between the entries in the two groups, this preliminary observation suggests that high yield potential is strongly associated with long pod filling period in bambara groundnut and that selection for yield increased maturing period of the improved varieties. Overall, the yields observed in this study were comparable to those in-season yields in Zimbabwe (Madamba, 1995), Tanzania (Collinson et al., 2000) and South Africa (Swanevelder, 1998). There is, therefore, potential for off-season cultivar development from the current germplasm.

Cultivar $\times$ planting date effects. Planting date $\times$ cultivar interaction effects were significant $(\mathrm{P}<0.05)$ for days to $50 \%$ emergence and number of pods plant ${ }^{-1}$, but were not significant for dry pod yield ha-1. Similar results of yield stability in bambara groundnut varieties were reported by Masindeni (2006) in preliminary G × E work in South Africa. Thus, overall, cultivars were relatively yield stable and did not display any specific adaptation to planting dates. This is further supported by the fact that genotypes showed consistence in yield ranking in all planting dates. These results contrast with the reports by Linnemann (1994) and Karikari et al. (1995), who reported differential cultivar adaptation to different production conditions although they worked with different cultivars. In this regard, further studies are needed in many locations to ascertain stability of the traits across sites and environments because, although four environments were used, this study was conducted on one location.

Significant planting date $\times$ variety interaction effects are presented in Figure 2. According to Fox et al. (1997), planting dates that are at $90^{\circ}$ in the biplot have correlations of variety $x$ environment interaction effects close to zero, implying that they rank varieties differently whereas those above or below $90^{\circ}$ have negative and positive correlations, respectively, meaning they invert the rank or rank varieties similarly. In this regard, for days to $50 \%$ emergence, the AP
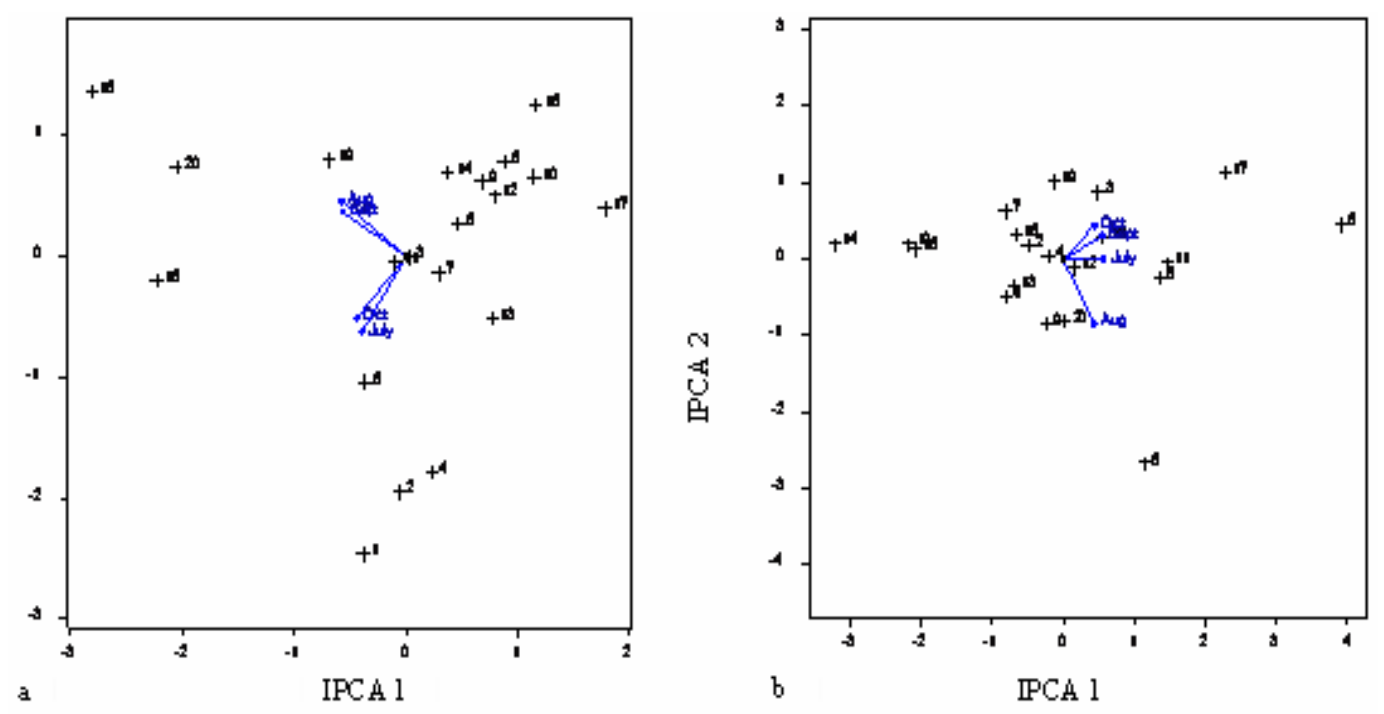

Figure 2. Principal Component biplot of the (a) days to $50 \%$ emergence and (b) number of pods plant ${ }^{-1}$ for the 20 cultivars (120) over the four planting dates in Zimbabwe. 
and SP were positively correlated and so were the OP and JP (Fig. 2a) that they had a similar variety ranking. However, the two groups had close to zero correlation between them meaning the groups ranked the varieties differently. For number of pods plant ${ }^{-1}$, SP and OP were highly and positively correlated, whereas a weak positive correlation existed between JP and AP (Fig. 2b). AP had a weak negative correlations with both SP and OP.

With respect to number of days to $50 \%$ emergence, varieties BG-MIA, Mbare, and 3804/ 90 were closely associated with the AP and OP; while Chipofu, Misodzi, Tulimara S2, and Tulimara S1 were closely associated with the OP and JP. The remaining 13 of the 20 varieties displayed no special relationship with planting date (Fig. 2a). These varieties supported the general adaptation observed in dry pod yield. This implies that selections on one planting date would be recommended for all planting dates. With respect to number of pods plant ${ }^{-1}$, varieties BS520, Mbare, BS534, and Variety-10 had high interaction effects with the SP; 3804/90, Ndebvu and Misodzi were associated with the OP; BS599, BS537; and Chipofu showed high interaction effects with the JP; whereas BG-MIA and V2-17 were associated with the SP (Fig. 2b). The observation of possible adaptation of genotypes to specific dates could be explained by the effects of temperature and photoperiod differentials during their growth and development, especially podding as reported in previous findings (Nikishitani et al., 1980; Linnemann, 1991, 1993, 1994; Linnemann and Azam-Ali, 1993; Mkandawire and Sibuga, 2002). This implies that there is a possibility of selecting for specific adaptation to different planting times; but eight of the 20 varieties did not show any special relationship with planting dates, and supported the observation of general adaptation shown by overall pod yield.

\section{CONCLUSIONS}

It is feasible to develop bambara groundnut varieties for early planting from the current germplasm in Zimbabwe. August and September are the optimum planting times for an off-season bambara groundnut crop. Lack of planting date $\times$ variety interaction on dry pod yield suggests general adaptation, implying that selection for early planting could be done at any one planting times evaluated with results being applicable to the other planting times. Varieties BS 599, BS 537, V2-17, BS 520, and Variety-10, with high relative yield, are the most promising and are advanced for further off-season evaluation.

\section{ACKNOWLEDGEMENTS}

Authors thank the Department of Agricultural Research and Extension in Zimbabwe for funding and hosting the trial. We also want to thank Mrs. Maodza and her team for helping in the implementation of the trial.

\section{REFERENCES}

Chibudu, C. 1995. An overview of bambara groundnut production and research by the Farming Systems Research Unit (FSRU) in Zimbabwe: a case study in the Chivi Communal area. In: Heller, J. Begemann, F. and Mushonga, J. (eds.), pp 98-100. Bambara Groundnut (Vigna subterranea L. Verdc.). Promoting the Conservation and Use of underutilised and Neglected Crops. 9. Proceeding of Workshop on Conservation and Improvement of Bambara Groundnuts (Vigna subterranea L. Verdc.), 14-16 November 1995, Harare, Zimbabwe.

Collinson, S.T., Sibuga, K.P., Tarimo, A.J.P. and Azam-Ali, S.N. 2000. Influence of sowing date on the growth and yield of bambara groundnut landraces in Tanzania. Experimental Agriculture 36:1-13.

Fox, P.N., Crossa, J. and Ramagossa, I. 1997. Multienvironment testing and genotype $\mathrm{x}$ environment interaction. In: Kempton, R.A. and Fox, P.N. (Eds.), pp. 117-138. Statistical Methods for Plant Varietal Evaluation. Chapman and Hall.

GAISMA. 2007. Harare, Zimbabwe - Sunrise, sunset, dawn and dusk times. http:// www.gaisma.com/en/location/harare.html (Accessed 20 November 2007).

Karikari, S.K., Wigglesworth, D.J., Kwerepe, B.C., Balole, T.V., Sebolai, B. and Munthali, D.C. 1995. Country report: Botswana. In: Heller, J. Begemann, F., and Mushonga, J. (Eds.), pp 
11-18. Bambara Groundnut (Vigna subterranea L. Verdc.). Promoting the Conservation and Use of underutilised and Neglected Crops. 9. Proceeding of Workshop on Conservation and Improvement of Bambara Groundnuts (Vigna subterranea L. Verdc.), 14-16 November 1995, Harare, Zimbabwe.

Linnemann, A.R. 1991. Preliminary observations on photoperiod regulation of phenological development in bambara groundnut (Vigna subterranea). Field Crop Research 26:295304.

Linnemann, A.R. 1993. Phenological development in Bambara groundnut (Vigna subterannea) at constant exposure to photoperiods of 1016h. Annals of Botany 71:445-452.

Linnemann, A.R. and Azam-Ali, S.N. 1993. Bambara groundnut (Vigna subterranea L. Verdc). In: Williams, J.T. (Ed.), pp. 13-58. Under-utilised Crops Series. II. Vegetable and Pulses. Chapman and Hall, London, UK.

Linnemann, A.R. 1994. Photothermal regulation of phenological development and growth in bambara groundnut [Vigna subterranea (L.) Verdc.]. PhD Thesis, Wageningen Agricultural University, The Netherlands.

Madamba, R. 1995. Breeding bambara groundnuts varieties suitable for Zimbabwean conditions. In: Heller, J. Begemann, F. and Mushonga, J. (Eds.), pp. 128-134. Bambara Groundnut (Vigna subterranea L. Verdc.). Promoting the Conservation and Use of underutilised and
Neglected Crops. 9. Proceeding of Workshop on Conservation and Improvement of Bambara Groundnuts (Vigna subterranea L. Verdc.), 14-16 November 1995, Harare, Zimbabwe.

Masindeni, D.R. 2006. Evaluation of bambara groundnut (Vigna subterranea) for yield stability and yield related characteristics. MSc. Dissertation, University of the Free State, Free State, Republic of South Africa.

Mkandawire, F.L. and Sibuga, K.P. 2002. Yield response of bambara groundnut to plant population and seedbed type. African Crop Science Journal 10:39-49.

Nehanda, G. 2000. The effects of three animalpowered tillage systems on soil-plant-water relations and maize cropping in Zimbabwe. D.Phil. thesis. Department of Soil Science and Agricultural Engineering, Faculty of Agriculture, University of Zimbabwe.

Nikishitani, T., Muruki, K. and Inouye, J. 1988. Effects of daylength on the flowering and fruiting in bambara groundnut (Vigna subterranea L. Verdc.). Japanese Journal of Tropical Agriculture 32:80-84.

Payne, R.W., Murray, D.A., Harding, S.A., Baird, D.B. and Soutar, D.M. 2007. GenStat for Windows (10 th Edition) Introduction. VSN International, Hemel Hempstead.

Swanevelder, C.J. 1998. Bambara - food for Africa. National Department of Agriculture, Government Printer, Republic of South Africa. 